\title{
Analysis of prognostic factors for overall survival in patients with advanced non-small cell lung cancer treated with second line chemotherapy
}

\author{
Milan Rancic ${ }^{*}$, Lidija Ristic, Marina Cekic, Tatjana Pejcic \\ Department for Pulmonary Oncology, Clinic for Lung Diseases, Clinical Center Nis, Nis, Serbia; \\ *Corresponding Author: milanrancic@gmail.com \\ Received 12 May 2013; revised 15 June 2013; accepted 24 June 2013 \\ Copyright (C) 2013 Milan Rancic et al. This is an open access article distributed under the Creative Commons Attribution License, \\ which permits unrestricted use, distribution, and reproduction in any medium, provided the original work is properly cited.
}

\begin{abstract}
Aim: The aim of this study was to investigate prognostic factors for survival in patients with advanced NSCLC who receiving second-line chemotherapy. Methods: We retrospectively reviewed data of 116 patients with NSCLC receiving second-line treatments from October 2010 to December 2012 in Clinic for Lung Diseases of Clinical center Nis, Department for Pulmonary Oncology. Thirteen potential prognostic factors were chosen for analysis. Univariate analysis was conducted to identify prognostic factors associated with progression free survival and overall survival. Multivariate analysis included the prognostic significance factors in univariate analysis. Results: The univariate analysis for progression free survival (PFS) and overall survival (OS) was identified to have prognostic significance: performance status, smoking, weight loss, comorbidity, number of meta localization, first-line chemotherapy regimen and response to first-line chemotherapy. Nevertheless, multivariate Cox prortional hazard regression analysis showed that performance status (PFS: $p=$ 0.000 , OS: $p=0.000$ ) weight loss $\geq 5 \%$ (PFS: $p=$ 0.000 , OS: $p=0.002$ ), comorbidity (PFS: $p=$ 0.001 , OS: $p=0.012$ ) and four places of meta localization (PFS: $p=0.021$, OS: $p=0.021$ ) were considered independent prognostic factors for both, progression free survival and overall survival. Conclusion: Performance status, weight loss $\geq 5 \%$, comorbidity and higher number of meta localization were identified as prognostic factors for survival in advanced NSCLC patients receiving second-line chemotherapy treatment. These findings may help pretreatment prediction
\end{abstract}

of survival and may facilitate in the future integration new agents into second-line treatment.

Keywords: Carcinoma; Non-Small Cell Lung Cancer; Treatment Protocol; Prognosis; Survival

\section{INTRODUCTION}

Lung cancer is the leading cause of cancer-related mortality in both men and women in world and it is estimated that more patients will die of lung cancer than of breast, colon, and prostate cancer combined [1].

Non-small cell lung cancer (NSCLC) represents between $80 \%$ to $85 \%$ of all the diagnosed lung cancers cases [2]. For approximately two thirds of NSCLC patients who present with advanced-stage disease, generally defined as stage IIIB or stage IV disease, the primary treatment is chemotherapy [3]. At the time of diagnosis, two-third of patients with lung cancer are diagnosed with locally advanced or metastatic disease. Only $15.6 \%$ of all lung cancer patients are alive 5 years or more after diagnosis [4].

A significant percentage of patients who present with local or locoregional disease will relapse with metastatic disease. For patients who have a good performance status (PS), chemotherapy has been shown to produce longer survival, palliate disease-related symptoms, and produce a better quality of life than with best supportive care (BSC) [3]. Many patients benefit from initial treatment with chemotherapy, although all patients eventually experience disease progression, generally within a median of 3 - 6 months of initiating chemotherapy [5]. Patients who have a good performance status benefit from platinum based regimen chemotherapy [6,7]. Phase III randomized trials have shown that many of the platinumdoublet combination yield similar objective response 
rates and survival $[5,8]$.

Patients with advanced NSCLC experience disease progression require second-line therapy. While it is difficult to estimate the proportion of patients who receive second-line treatment, approximately $40 \%-50 \%$ of patients did so in recent first-line trials $[9,10]$. Patients who appear more likely to receive second-line therapy are those with a good PS, female patients, and those with non-squamous histology [11]. Reported response rate to second-line chemotherapy has generally been less than $10 \%$. Docetaxel, pemetrexed, erlotinib, or platinum doublet (with or without bevacizumab) are recommended as second-line chemotherapy regimens for patients with performance status 0 - 2 and who have experienced disease progression during and after first-line therapy [12]. In spite of clinical benefit of second-line treatments, toxic side effects are often observed. There are reliable predictors to identify patients for first-line chemotherapy, but prognostic factors are not sufficiently predictive of second-line treatment efficacy.

The aim of this study was to investigate prognostic factors for survival in patients with advanced NSCLC who receiving second-line chemotherapy.

\section{MATERIALS AND METHODS}

\subsection{Patient Population}

We retrospectively reviewed 116 patients with NSCLC receiving second-line treatments from October 2010 to December 2012 in the Clinic for lung diseases of Clinical center Nis, Department of Pulmonary Oncology.

They met the following inclusion criteria; 1) histologic or cytologic diagnosis of Stage IIIB or IV NSCLC; 2) 18 years or older in age; 3) receiving Evaluation Criteria in Solid Tumors (RECIST) [13]; 4) performance status ECOG 0-2 [14].

\subsection{Factors Analyzed}

13 potential prognostic variables were chosen on the basis of previously published clinical trials. The variables were divided to categories: 1 ) age ( $<65$ or $\geq 65$ years), 2 ) gender (male or female), 3) stage of disease at diagnosis (IIIB or IV), 4) histology (adenocarcinoma, squamous or non-small cell lung cancer), 5) smoking history (actual, former smoker or never smoker), 6) performance status (ECOG $0-1$ or 2), 7) weight loss $\geq 5 \%$ with previous 3 months (yes or no), 8) significant comorbidities (yes or no), 9) number of metastatic localizations $(0,1,2,3$, or 4), 10) first line chemotherapy regimen, 12) response to first line chemotherapy (yes or no), 12) second line chemotherapy regimen 13) response to second line chemotherapy (yes or no).

\subsection{Statistical Analysis}

PFS and OS were estimated using the Kaplan-Meier method. Log rank (Mantel-Cox) test were used for testing the differences among categories of factor. The Cox proportional hazards regression model was used to determine statistical significant variables related to survival. Overall survival was calculated from the start of first cycle of first-line chemotherapy to the date of death from any cause or date of the last follow-up control. PFS was defined as the time from first cycle of first-line chemotherapy till progression. All of the analyses were performed using the Statistical Software Program Package (SPSS v 20 for Windows).

\section{RESULTS}

Between October 2010 to December 2012, 116 patients received a second line treatment on time of progression of disease after first-line chemotherapy. The median age of patients was 58.48 years (range 19 - 74) with $95(81.9 \%)$ males and $21(18.1 \%)$ females. The number of patients with a PS score 0 - 1 was $77(66.4 \%)$. $22(19 \%)$ were diagnosed as having stage IIIB and 94 patients $(81 \%)$ had stage IV.

Squamous carcinoma was the most common histologic type $63(54.3 \%)$. There was not a significant difference between men and women in frequency adenocarcinoma or squamous carcinoma. (33 vs 10 for adenocarcinoma and 54 vs 9 for squamous carcinoma, Pearson ChiSquare: $1.414, \mathrm{p}=0.493$ ).

Among patients receiving second-line therapy, median OS was 11.65 (2.7 - 25.2) months and median PFS was 8.02 (3 - 23) months (Table 1).

The results of univariate analysis for PFS and OS are summarized in Table 2. Among the thirteen variables of univariate analysis, seven variables were identified to have prognostic significance for PFS: performance status $(\mathrm{p}=0.000)$, smoking $(\mathrm{p}=0.003)$, weight loss $>5 \%(\mathrm{p}=$ $0.000)$, comorbidities $(p=0.000)$, number of meta localization $(\mathrm{p}=0.000)$, first-line chemotherapy regimen $(\mathrm{p}=$ $0.000)$ and response to first-line chemotherapy $(p=0.000)$.

Among the thirteen variables of univariate analysis of OS, five variables were identified to have prognostic significance: performance status $(\mathrm{p}=0.000)$, weight loss $>5 \%(\mathrm{p}=0.000)$, comorbidities $(\mathrm{p}=0.000)$, number of meta localization $(p=0.000)$, and response to first-line chemotherapy $(\mathrm{p}=0.044)$.

Multivariate analysis included prognostic significance factors in univariate analysis (Tables 3 and 4).

Multivariate analysis by Cox proportional hazard model showed that performance status $(p=0.000)$, weight loss $>5 \%(p=0.002)$, comorbidity $(p=0.012)$ and number of meta localization $(3 ; \mathrm{p}=0.047$, and $4 ; \mathrm{p}=$ 0.021 ) were considered independent prognostic factors for OS. Nevertheless, performance status $(p=0.005)$, 
Table 1. Patients characteristics.

\begin{tabular}{|c|c|c|}
\hline Characteristic & & $\begin{array}{l}\text { No. of patients } \\
(\%)\end{array}$ \\
\hline \multirow[t]{2}{*}{ Sex } & Male & $95(81.9)$ \\
\hline & Female & $21(18.1)$ \\
\hline \multirow[t]{3}{*}{ Age } & Median (range) & $58.48(19-74)$ \\
\hline & $<65$ & $96(82.8)$ \\
\hline & $\geq 65$ & $20(17.2)$ \\
\hline \multirow[t]{2}{*}{ Performance status } & $0-1$ & $77(66.4)$ \\
\hline & 2 & $39(33.6)$ \\
\hline \multirow[t]{3}{*}{ Smoking history } & Current & $45(38.8)$ \\
\hline & Former & $54(46.6)$ \\
\hline & Never & $12(10.3)$ \\
\hline \multirow[t]{2}{*}{ Weight loss $>5 \%$} & Yes & $58(50)$ \\
\hline & No & $58(50)$ \\
\hline \multirow[t]{2}{*}{ Comorbidity } & Yes & $62(53.4)$ \\
\hline & No & $54(46.6)$ \\
\hline \multirow[t]{2}{*}{ Stage } & IIIB & $22(19)$ \\
\hline & IV & $94(81)$ \\
\hline \multirow[t]{3}{*}{ Histology } & Adenocarcinoma & $43(37.1)$ \\
\hline & Squamous & $63(54.3)$ \\
\hline & Non-small cell & $10(8.6)$ \\
\hline \multirow[t]{5}{*}{ No meta localization } & 0 & $22(19.0)$ \\
\hline & 1 & $44(37.9)$ \\
\hline & 2 & $26(22.4)$ \\
\hline & 3 & $20(17.2)$ \\
\hline & 4 & $4(3.4)$ \\
\hline \multirow[t]{2}{*}{$\begin{array}{l}\text { First line chemotherapy } \\
\text { regimen }\end{array}$} & $\begin{array}{l}\text { Etoposide/Cisplatin } \\
\text { (EP) }\end{array}$ & $39(33.6)$ \\
\hline & $\begin{array}{c}\text { Gemcitabine/Cisplatin } \\
\text { (GC) }\end{array}$ & $77(66.4)$ \\
\hline \multirow[t]{2}{*}{$\begin{array}{l}\text { First line chemotherapy } \\
\text { response }\end{array}$} & Partial Response (PR) & $69(59.5)$ \\
\hline & Stable Disease (SD) & $47(40.5)$ \\
\hline \multirow[t]{6}{*}{$\begin{array}{l}\text { Second line } \\
\text { chemotherapy } \\
\text { Regimen }\end{array}$} & $\begin{array}{l}\text { Etoposide/Cisplatin } \\
\text { (EP) }\end{array}$ & $7(6)$ \\
\hline & $\begin{array}{c}\text { Gemcitabine/Cisplatin } \\
\text { (GC) }\end{array}$ & $31(26.7)$ \\
\hline & Gemcitabine mono $(\mathrm{G})$ & $2(1.7)$ \\
\hline & $\begin{array}{c}\text { Paclitaxel/Carboplatin } \\
\text { (PC) }\end{array}$ & $48(41.4)$ \\
\hline & Docetaxel $(\mathrm{T})$ & $10(8.6)$ \\
\hline & Erlotinib (Tar) & $18(15.5)$ \\
\hline \multirow{2}{*}{$\begin{array}{l}\text { Second line } \\
\text { chemotherapy } \\
\text { response }\end{array}$} & Partial Response (PR) & $83(71.6)$ \\
\hline & Stable Disease (SD) & $33(28.4)$ \\
\hline \multirow[t]{2}{*}{$\begin{array}{l}\text { Progression free } \\
\text { survival }\end{array}$} & Median (Range) & $8.02(3-23)$ \\
\hline & Mean & 8.78 \\
\hline \multirow[t]{2}{*}{ Overall survival } & Median (Range) & $11.65(2.7-25.2)$ \\
\hline & Mean & 12.48 \\
\hline
\end{tabular}

Table 2. Univariate analysis by categorical variable.

\begin{tabular}{|c|c|c|c|c|}
\hline \multirow[t]{2}{*}{ Characteristic } & \multicolumn{2}{|c|}{$\begin{array}{c}\text { Progression Free } \\
\text { Survival (PFS) }\end{array}$} & \multicolumn{2}{|c|}{ Overall Survival (OS) } \\
\hline & $\begin{array}{l}\text { Log-rank } \\
\text { test value }\end{array}$ & $\mathrm{p}^{\dagger}$ & $\begin{array}{l}\text { Log-rank } \\
\text { test value }\end{array}$ & $\mathrm{p}^{\dagger}$ \\
\hline Sex & 0.931 & 0.334 & 1.708 & 0.191 \\
\hline Age & 0.944 & 0.331 & 0.274 & 0.601 \\
\hline Performance status & 71.031 & 0.000 & 63.878 & 0.000 \\
\hline Smoking history & 11.540 & 0.003 & 1.325 & 0.515 \\
\hline Weight loss $>5 \%$ & 89.150 & 0.000 & 38.050 & 0.000 \\
\hline Comorbidities & 39.738 & 0.000 & 34.295 & 0.000 \\
\hline Stage & 0.221 & 0.638 & 0.063 & 0.802 \\
\hline Histology & 0.648 & 0.723 & 0.151 & 0.927 \\
\hline No meta localization & 100.630 & 0.000 & 65.652 & 0.000 \\
\hline $\begin{array}{l}\text { First line } \\
\text { chemotherapy } \\
\text { regimen }\end{array}$ & 100.630 & 0.000 & 0.023 & 0.879 \\
\hline $\begin{array}{l}\text { First line } \\
\text { chemotherapy } \\
\text { response }\end{array}$ & 18.861 & 0.000 & 4.058 & 0.044 \\
\hline $\begin{array}{l}\text { Second line } \\
\text { chemotherapy } \\
\text { Regimen }\end{array}$ & 1.327 & 0.932 & 7.855 & 0.164 \\
\hline $\begin{array}{l}\text { Second line } \\
\text { chemotherapy } \\
\text { response }\end{array}$ & 1.140 & 0.286 & 0.012 & 0.914 \\
\hline
\end{tabular}

${ }^{\dagger}$ significant $\mathrm{p}<0.05$.

weight loss $>5 \%(p=0.000)$, comorbidities $(p=0.001)$ and number of meta localization $(4 ; p=0.047)$ were considered independent prognostic factors for PFS (Tables 3 and 4). Survival of patients according to prognostic factors for OS shown on Figures 1-4.

\section{DISCUSSION}

Platinum-based chemotherapy in advanced NSCLC is considered the first choice, which presents a modest survival advantage. Combinations using many of drugs (cisplatin. carboplatin, paclitaxel, docetaxel, vinorelbine, gemcitabine, etoposide, pemetrexed) produce 1-year survival rates of $30 \%-40 \%$ and are superior to single agents [12]. Patients with advanced NSCLC eventually experience disease progression and require second-line therapy. While the prognostic factors associated with improved survival with first-line therapy have been extensively studied, less information exists about the prognostic factors in second-line therapy. For the treating physician, prognostic factors may assist in determining the likelihood of clinical benefit of further therapy. Identifying prognostic factors is of enormous importance in order to select candidates to prolonged treatment, and avoid futile chemotherapy for poor prognosis patients that will not respond to treatment. Recently, different 
Table 3. Multivariate analysis of prognostic factors for progression free survival.

\begin{tabular}{cccc}
\hline & $\mathrm{p}^{\dagger}$ & $\mathrm{HR}^{*}$ & $95 \%$ CI§ of HR \\
\hline Performance status & 0.005 & 0.340 & $0.161-0.716$ \\
Smoking: current & 0.320 & 1.501 & $0.674-3.346$ \\
Smoking: former & 0.845 & 1.086 & $0.474-2.489$ \\
Weight loss $>5 \%$ & 0.000 & 0.109 & $0.053-0.227$ \\
Comorbidities & 0.001 & 0.320 & $0.163-0.630$ \\
No meta localization: 1 & 0.098 & 0.570 & $0.293-1.109$ \\
No meta localization: 2 & 0.396 & 0.730 & $0.352-1.511$ \\
No meta localization: 3 & 0.420 & 0.703 & $0.298-1.657$ \\
No meta localization: 4 & 0.021 & 5.467 & $1.293-23.114$ \\
First line chemotherapy & 0.464 & 1.220 & $0.717-2.075$ \\
regimen & & & $0.333-1.056$ \\
First line chemotherapy & 0.076 & 0.593 & \\
response & & &
\end{tabular}

${ }^{\dagger}$ significant $\mathrm{p}<0.05,{ }^{*}$ Hazard ratio, § Confidence interval.

Table 4. Multivariate analysis of prognostic factors for overall survival.

\begin{tabular}{cccc}
\hline & $\mathrm{p}^{\dagger}$ & $\mathrm{HR}^{*}$ & $95 \% \mathrm{CI}$ of HR \\
\hline Performance status & 0.000 & 0.219 & $0.097-0.493$ \\
Weight loss $>5 \%$ & 0.002 & 0.268 & $0.117-0.612$ \\
Comorbidities & 0.012 & 0.386 & $0.184-0.809$ \\
No meta localization: 1 & 0.333 & 0.651 & $0.273-1.552$ \\
No meta localization: 2 & 0.954 & 0.973 & $0.384-2.467$ \\
No meta localization: 3 & 0.047 & 2.932 & $1.016-8.462$ \\
No meta localization: 4 & 0.021 & 9.315 & $1.401-61.948$ \\
First line chemotherapy & 0.408 & 1.341 & $0.669-2.690$ \\
response & & & \\
\hline
\end{tabular}

${ }^{\dagger}$ significant $\mathrm{p}<0.05,{ }^{*}$ Hazard ratio, § Confidence interval.

studies have been shown that wrong selection of patients lead to chemotherapy administered near the end of life, without benefits and probably these treatments have worsened quality of life near the end [15].

Docetaxel, pemetrexed and erlotinib are recommended as second-line chemotherapy for the NSCLC patients. Docetaxel has been proven superior to the best supportive care, ifosfamide or vinorelbine with improved survival and quality of life $[16,17]$. Pemetrexed is recommended in patients with adenocarcinoma or large cell histology [18].

Bonomi et al. [19] reported the prognostic factors in a second-line trial that compared docetaxel with paclitaxel poliglumex (PPX) in 849 patients. There was no difference in survival between the two treatment arms. The following factors were associated with shorter survival: an Eastern Cooperative Oncology Group PS score of 2 versus 0 - 1 (HR, 2.19; $\mathrm{p}<0.001$ ), a hemoglobin level of

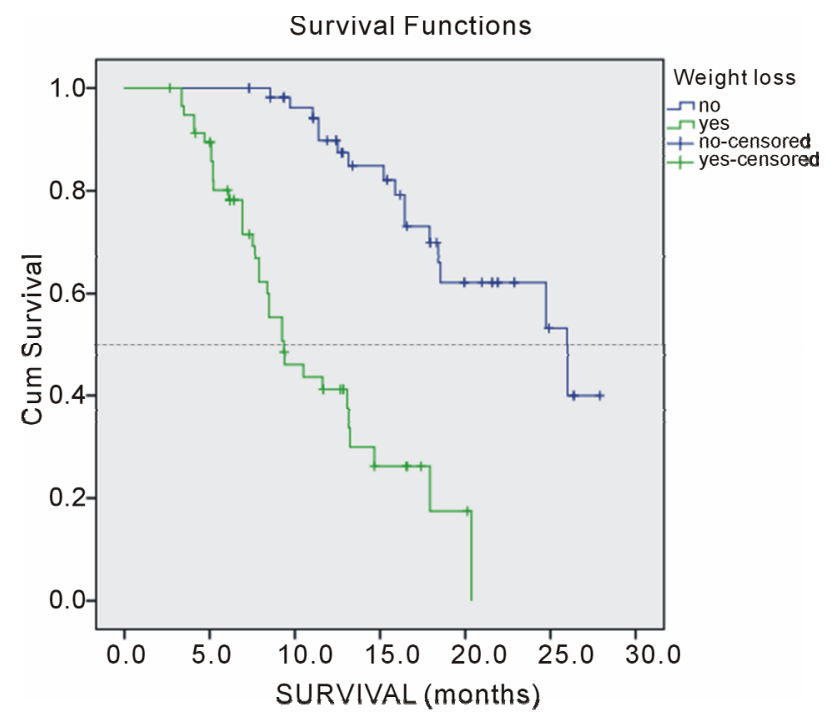

Figure 1. Overall survival of patients according weight loss.

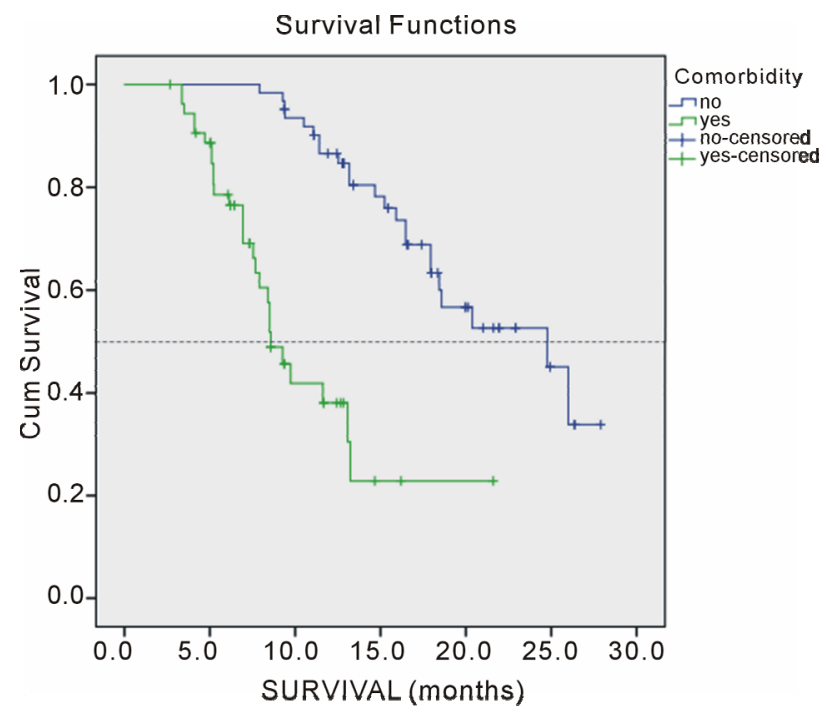

Figure 2. Overall survival of patients according comorbidity.

$<11 \mathrm{~g} / \mathrm{dl}$ versus $\geq 11 \mathrm{~g} / \mathrm{dl}$ (HR, 1.78; $<<0.001)$, an LDH level of $<200 \mathrm{U} / 1$ versus $\geq 200 \mathrm{U} / 1$ (HR, $1.72 ; \mathrm{p}<0.001$ ), a lung cancer symptom score of $<18$ versus $\geq 18$ (HR, 1.47; $\mathrm{p}<0.001$ ), male gender (HR, $1.39 ; \mathrm{p}=0.005$ ), extrathoracic metastases (HR, $1.45 ; \mathrm{p}<0.001)$, prior radiation therapy (HR, 1.40; $\mathrm{p}=0.001)$, and starting second-line chemotherapy $<4$ months after the start of first-line chemotherapy (HR, 1.37; $\mathrm{p}=0.003)$.

Younes RN et al. [20] in prognostic analysis disclosed that among 2673 included patients, female gender, higher performance status, histology non-large-cell carcinoma, receive any chemotherapy, objective response to firstline chemotherapy, and receive second-line chemotherapy were determinants of better overall survival. However, at multivariate analysis only performance status, second-line chemotherapy and objective response to 


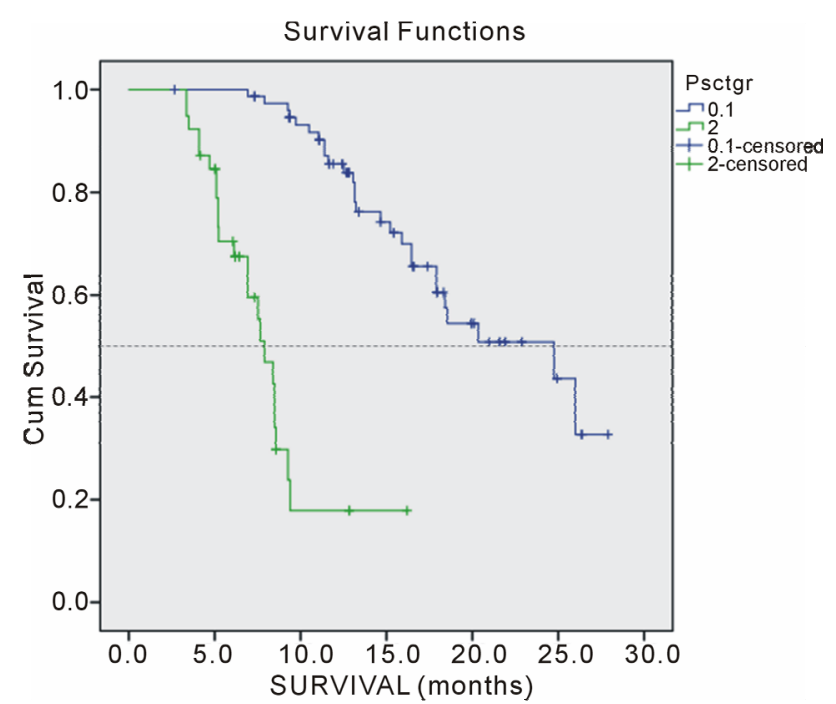

Figure 3. Overall survival of patients according performance status.

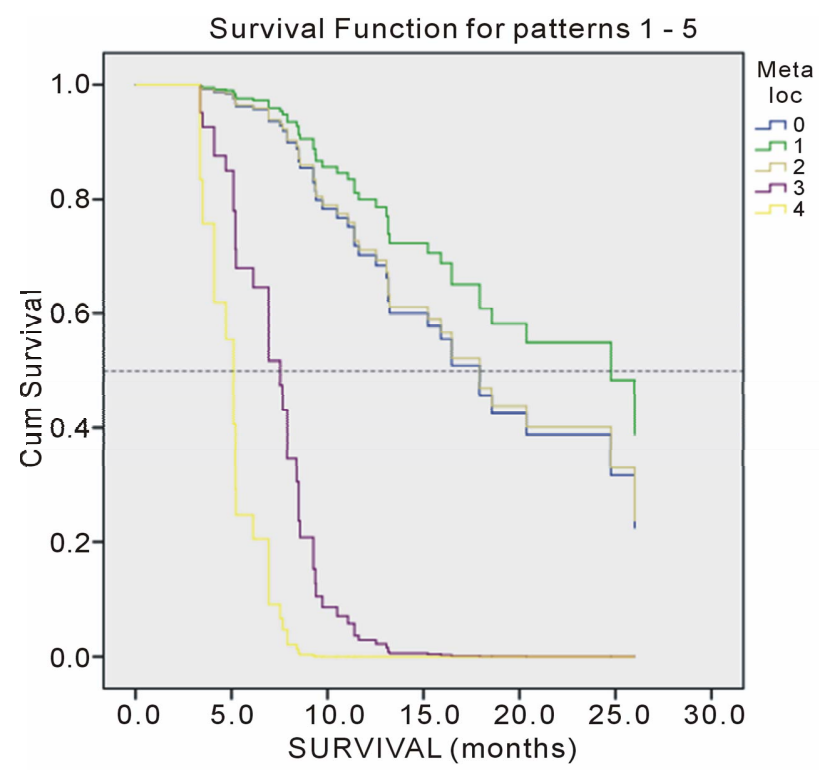

Figure 4. Overall survival of patients according number of meta localization.

first-line chemotherapy were independent determinants of prognosis.

The few prior studies did not show any significant interaction between the response to previous treatment and OS [21-23], but Maio et al. [24,25] and Weis et al. [26] found that response to previous chemotherapy had a predictive value for survival in advanced NSCLC. Inall A. et al. found that two characteristics of treatment were independently associated with OS: patients obtaining objective response during first-line therapy and objective response during second-line therapy [27]. Furthermore, performance status and response to second-line chemotherapy were considered independent prognostic factors for PFS. We found that only one characteristic of treatment were independently associated with longer PFS: objective response during first-line chemotherapy. Similar to our results, Zietemann et al. found that response to second-line tretament had no impact on PFS [21].

However, in our study, the objective response to first-line chemotherapy was not an independent prognostic factor of overall survival. Also, the objective response to second line chemotherapy were not significantly influenced both the survival time to progression, and the overall survival. This result indirectly indicates a possible delay in the implementation of secondary lines of chemotherapy. Similar to our results, Zietemann et al. found that response to second-line tretament had no impact on PFS [21].

The TAX 320 trial compared docetaxel at $100 \mathrm{mg} / \mathrm{m}^{2}$, docetaxel at $75 \mathrm{mg} / \mathrm{m}^{2}$, and a control arm of either vinorelbine $\left(30 \mathrm{mg} / \mathrm{m}^{2}\right)$ on days 1,8 , and 15 or ifosfamide $\left(2 \mathrm{mg} / \mathrm{m}^{2}\right.$ per day) on days $1-3$ every 3 weeks [17]. This trial did not reveal a difference in overall survival between the two treatment arms, but did reveal a difference in the 1-year survival rates [17]. Based on the results of phase II trials of single agent pemetrexed $[28,29]$ single-agent pemetrexed $\left(500 \mathrm{mg} / \mathrm{m}^{2}\right.$ every 3 weeks) with vitamin supplementation was compared with standarddose docetaxel every 3 weeks in a phase III clinical trial in advanced NSCLC [30]. Complicating the survival analysis in this study was the fact that $32 \%$ of the pemetrexed treated patients received docetaxel after disease progression. The other efficacy parameters, response rate and progression-free survival, were similar between the two treatment arms and suggested that the clinical benefits from pemetrexed and docetaxel would be similar. A Cox proportional multiple regression analysis found that a good PS score ( 0 - 1 versus 2$)$, disease stage (III versus IV), and longer time since first-line chemotherapy ( $\geq 3$ months versus $<3$ months) were associated with longer survival after second-line chemotherapy. The median survival time for patients with a PS score of 0 or 1 was 9 months in both treatment arms. A subset analysis of elderly patients ( $\geq 70$ years old) in that trial revealed no significant difference in median survival time between elderly and younger patients [31]. Elderly patients treated with pemetrexed had a survival time similar to that of elderly patients treated with docetaxel. The results of this study indicate insignificant prognostic significance of patient age and sex.

A poor PS is usually accepted a negative prognostic factor for all cancer patients [32,33]. Many patients who maintain a poor PS and no tolerate therapy due to toxicity experienced shorter PFS and OS than patients of a good PS.

Present study was identified PS as significant factor of successful tretment. Performance status in our study was significant prognostic impact on progressin disease (PFS) 
and overall survival. Also, the results of this retrospective study showed that two factors significant prognostic factors: weight loss in the last three months, more than $5 \%$, and comorbidities. These two factors act synergistically with one another and with the performance status. The presence of a large number of metastases in our patients was an important prognostic factor, but it is only significant for PFS target localization effect of changes in four localizations, while significantly prognostic for OS and the existence of three different target localization.

\section{CONCLUSIONS}

The results of our study were identified important prognostic factors for survival of advanced NSCLC patients receiving second-line treatment. Performance status, weight loss $\geq 5 \%$, important comorbidities and number of separate localization of metastasis were marked as significant prognostic factors for progression free survival and overall survival patients treated with secondline chemotherapy. Although response to first-line therapy by univariate analysis was identified as important factor for survival, multivariate analysis was not supported.

The results of our study have got some limitations, because this is retrospective study and there was a small number of patients, prospective and larger clinical trials are needed.

\section{REFERENCES}

[1] Jemal, A., Siegel, R., Ward, E., Murray, T., Xu, J. and Thun, M.J. (2007) Cancer statistics. CA-A Cancer Journal for Clinicians, 57, 43-66. doi:10.3322/canjclin.57.1.43

[2] Boyle, P. and Ferlay, J. (2004) Cancer incidence and mortality in Europe, 2004. Annals of Oncology, 16, 481-488. doi:10.1093/annonc/mdi098

[3] Socinski, M.A., Morris, D.E., Masters, G.A. and Lilenbaum, R. (2003) Chemotherapeutic management of stage IV non-small cell lung cancer. Chest, 123, 226S-243S. doi:10.1378/chest.123.1_suppl.226S

[4] Siegel, R., Ward, E., Brawley, O. and Jemal, A. (2011) Cancer statistics, 2011: The impact of eliminating socioeconomic and racial disparities on premature cancer deaths. CA-A Cancer Journal for Clinicians, 61, 212236. doi: $10.3322 /$ caac. 20121

[5] Schiller, J.H., Harrington, D., Belani, C.P., Langer, C., Sandler, A., Krook, J., Zhu, J. and Johnson, D.H. (2002) Comparison of four chemotherapy regimens for advanced non-small cell lung cancer. The New England Journal of Medicine, 346, 92-98. doi:10.1056/NEJMoa011954

[6] NSCLC Meta-Analyses Collaborative Group (2008) Chemotherapy in addition to supportive care improves survival in advanced non-small-cell lung cancer: A systematic review and meta-analysis of individual patient data from 16 randomized controlled trials. Journal of Clinical
Oncology, 26, 4617-4625. doi:10.1200/JCO.2008.17.7162

[7] Azzoli, C.G., Baker Jr., S., Temin, S., Pao, W., Aliff. T., Brahmer, J., Johnson, D.H., Laskin, J.L., Masters, G., Milton, D., Nordquist, L., Pfister, D.G., Piantadosi, S., Schiller, J.H., Smith, R., Smith, T.J., Strawn, J.R., Trent, D. and Giaccone, G. (2009) American society of clinical oncology clinical practice guideline update on chemotherapy for stage IV non-small-cell lung cancer. Journal of Clinical Oncology, 27, 6251-6266. doi:10.1200/JCO.2009.23.5622

[8] Kelly, K., Crowley, J., Bunn Jr., P.A., Presant, C.A., Grevstad, P.K., Moinpour, C.M., Ramsey, S.D., Wozniak, A.J., Weiss, G.R., Moore, D.F., Israel, V.K., Livingston, R.B. and Gandara, D.R. (2001) Randomized phase III trial of paclitaxel plus carboplatin versus vinorelbine plus cisplatin in the treatment of patients with advanced nonsmall cell lung cancer: A Southwest Oncology Group trial. Journal of Clinical Oncology, 19, 3210-3218.

[9] Sandler, A., Gray, R., Perry, M.C., Brahmer, J., Schiller, J.H., Dowlati, A., Lilenbaum, R. and Johnson, D.H. (2006) Paclitaxel-carboplatin alone or with bevacizumab for non-small cell lung cancer. The New England Journal of Medicine, 355, 2542-2550. doi:10.1056/NEJMoa061884

[10] Socinski, M.A., Schell, M.J., Peterman, A., Bakri, K., Yates, S., Gitten, R., Unger, P., Lee, J., Lee, J.H., Tynan, M., Moore, M. and Kies, M.S. (2002) Phase III trial comparing a defined duration of therapy versus continuous therapy followed by second-line therapy in advancedstage IIIB/IV non-small-cell lung cancer. Journal of Clinical Oncology, 20, 1335-1343. doi:10.1200/JCO.20.5.1335

[11] Hensing, T.A., Schell, M.J., Lee, J.H. and Socinski, M.A. (2005) Factors associated with the likelihood of receiving second line therapy for advanced non-small cell lung cancer. Lung Cancer, 47, 253-259. doi:10.1016/j.lungcan.2004.07.040

[12] NCCN Clinical Practice Guidelines in Oncology (2012) Non-small cell lung cancer. Version 2, MS30-MS31. http://www.nccn.com/

[13] Eisenhauer, E.A., Therasse, P., Bogaerts, J., Schwartz, L.H., Sargent, D., Ford, R., Dancey, J., Arbuck, S., Gwyther, S., Mooney, M., Rubinstein, L., Shankar, L., Dodd, L., Kaplan, R., Lacombe, D. and Verweij, J. (2009) New response evaluation criteria in solid tumours: Revised RECIST guideline (version 1.1). European Journal of Cancer, 45, 28-47. doi:10.1016/j.ejca.2008.10.026

[14] Oken, M.M., Creech, R.H., Tormey, D.C., Horton, J., Davis, T.E., McFadden, E.T., Carbone, P.P. (1982) Toxicity And Response Criteria Of The Eastern Cooperative Oncology Group. American Journal of Clinical Oncology, 5, 649-655. doi:10.1097/00000421-198212000-00014

[15] Zhang, X., Zang, J., Xu, J., Bai, C., Qin, Y., Liu, K., Wu, C., Wu, M., He, Q., Zhang, S., Wei, L. and He, J. (2011) Maintenance therapy with continuous or switch strategy in advanced non-small-cell lung cancer: A systematic review and meta-analysis. Chest, 140, 117-126. doi:10.1378/chest.10-2745

[16] Shepherd, F.A., Dancey, J., Ramlau, R., Mattson, K., Gralla, R., O'Rourke, M., Levitan, N., Gressot, L., Vincent, M., Burkes, R., Coughlin, S., Kim, Y. and Berille, J. 
(2000) Prospective randomized trial of docetaxel versus best supportive care in patients with non-small-cell lung cancer previously treated with platinum-based chemotherapy. Journal of Clinical Oncology, 18, 2095-2103.

[17] Fossella, F.V., DeVore, R., Kerr, R.N., Crawford, J., Natale, R.R., Dunphy, F., Kalman, L., Miller, V., Lee, J.S., Moore, M., Gandara, D., Karp, D., Vokes, E., Kris, M., Kim, Y., Gamza, F. and Hammershaimb, L. (2000) Randomized phase III trial of docetaxel versus vinorelbine or ifosfamide in patients with advanced non-small-cell lung cancer previously treated with platinum-containing chemotherapy regimens. The TAX 320 Non-Small Cell Lung Cancer Study Group. Journal of Clinical Oncology, 18, 2354-2362.

[18] Ciuleanu, T., Brodowicz, T., Zielinski, C., Kim, J.H., Krzakowski, M., Laack, E., Wu, Y.L., Bover, I., Begbie, S., Tzekova, V., Cucevic, B., Pereira, J.R., Yang, S.H., Madhavan, J., Sugarman, K.P., Peterson, P., John, W.J., Krejcy, K. and Belani, C.P. (2009) Maintenance pemetrexed plus best supportive care versus placebo plus best supportive care for non-small-cell lung cancer: A randomised, double-blind, phase 3 study. Lancet, 374, 14321440. doi:10.1016/S0140-6736(09)61497-5

[19] Bonomi, P., Langer, C., O'Brien, M., O’Byrne, K., Bandstra, B., Paz-Ares, L., Ross, H., Sandler, A. and Socinski, M. (2006) Analysis of prognostic factors in patients with advanced relapsed/refractory NSCLC: Cox regression analysis of a randomized phase III trial comparing docetaxel and paclitaxel poliglumex (PPX). Journal of Clinical Oncology, 24, 374s.

[20] Younes, R.N., Pereira, J.R., Fares, A.L. and Gross, J.L. (2011) Chemotherapy beyond first-line in stage IV metastatic non-small cell lung cancer. Revista da Associação Médica Brasileira, 57, 686-691. doi:10.1590/S0104-42302011000600017

[21] Zietemann, V. and Duell, T. (2011) Prevalence and effectiveness of firs-, second-, and third-line systemic therapy in cohort of unselected patients with advanced non-small cell lung cancer. Lung Cancer, 73, 70-77. doi:10.1016/j.lungcan.2010.10.017

[22] Scartozzi, M., Mazzanti, P., Giampieri, R., Berardi, R., Galizia, E., Gasparini, S., Zuccatosta, L. and Cascinu, S. (2010) Clinical predictive factors for advanced non-small cell lung cancer (NSCLC) patients receiving third-line therapy: Selecting the unselectable? Lung Cancer, 68, 433-437. doi:10.1016/j.lungcan.2009.07.008

[23] Wataya, H., Okamoto, T., Maruyama, R., Seto, T., Yamazaki, K., Tagawa, T., Fukuyama, S., Osoegawa, A., Ikeda, J., Nishimura, M., Yamanaka, T. and Ichinose, Y. (2009) Prognostic factors in previously treated non-small cell lung cancer patients with and without a positive response to the subsquent treatment with gefitinib. Lung Cancer, 64, 341-345. doi:10.1016/j.lungcan.2008.09.005

[24] Di Maio, M., Lama, N., Morabito, A., Smit, E.F., Georgoulias, V., Takeda, K., Quoix, E., Hatzidaki, D., Wachters, F.M., Gebbia, V., Tsai, C.M., Camps, C., Schuette, W., Chiodini, P., Piccirillo, M.C., Perrone, F., Gallo, C. and Gridelli, C. (2010) Clinical assessment of patients with advanced non-small-cell lung cancer eligible for second-line chemotherapy: A prognostic score from individual data of nine randomised trials. European Journal of Cancer, 46, 735-743. doi:10.1016/j.ejca.2009.12.013

[25] Di Maio, M., Krzakowski, M., Fougeray, R., Kowalski, D.M. and Gridelli, C. (2012) Prognostic score for secondline chemotherapy of advanced non-small-cell lung cancer: External validation in a phase III trial comparing vinflunine with docetaxel. Lung Cancer, 77, 116-120. doi:10.1016/j.lungcan.2012.01.013

[26] Weiss, G.J., Rosell, R., Fossella, F., Perry, M., Stahel, R., Barata, F., Nguyen, B., Paul, S., McAndrews, P., Hanna, N., Kelly, K., Bunn Jr., P.A., (2007) The impact of induction chemotherapy on the outcome of second-line therapy with pemetrexed or docetaxel in patients with advanced non-small-cell lung cancer. Annals of Oncology, 18, 453460. doi:10.1093/annonc/mdl454

[27] Inal, A., Kaplan, M.A., Kucukoner, M., Urakci, Z., Karakus, A. and Isikdogan, A. (2012) Prognostic factors for second-line tretment of advanced non-small-cell Lung Cancer: Retrospective analysis at a single institution. Asian Pacific Journal of Cancer Prevention, 13, 12811284. doi:10.7314/APJCP.2012.13.4.1281

[28] Smit, E.F., Mattson, K., von Pawel, J., Manegold, C., Clarke, S. and Postmus, P.E. (2003) ALIMTA (pemetrexed disodium) as second-line treatment of non-small-cell lung cancer: A phase II study. Annals of Oncology, 14, 455-460. doi:10.1093/annonc/mdg099

[29] Rusthoven, J.J., Eisenhauer, E., Butts, C., Gregg, R., Dancey, J., Fisher, B. and Iglesias, J. (1999) Multitargeted antifolate LY231514 as first-line chemotherapy for patients with advanced nonsmall-cell lung cancer: A phase II study. National Cancer Institute of Canada Clinical Trials Group. Journal of Clinical Oncology, 17, 1194.

[30] Hanna, N., Shepherd, F.A., Fossella, F.V., Pereira, J.R., De Marinis, F., von Pawel, J., Gatzemeier, U., Tsao, T.C., Pless, M., Muller, T., Lim, H.L., Desch, C., Szondy, K., Gervais, R., Shaharyar, Manegold, C., Paul, S., Paoletti, P., Einhorn, L. and Bunn Jr., P.A., (2004) Randomized phase III trial of pemetrexed versus docetaxel in patients with non-small-cell lung cancer previously treated with chemotherapy. Journal of Clinical Oncology, 22, 15891597. doi:10.1200/JCO.2004.08.163

[31] Weiss, G.J., Langer, C. and Rosell, R. (2006) Elderly patients benefit from second-line cytotoxic chemotherapy: A subset analysis of a randomized phase III trial of pemetrexed compared with docetaxel in patients with previously treated advanced non-small-cell lung cancer. Journal of Clinical Oncology, 24, 4405-4411. doi:10.1200/JCO.2006.06.7835

[32] Kim, J.G., Ryoo, B.Y., Park, Y.H., Kim, B.S., Kim, T.Y., Im, Y.H. and Kang, Y.K. (2008) Prognostic factors for survival of patients with advanced gastric cancer treated with cisplatin-based chemotherapy. Cancer Chemotherapy and Pharmacology, 61, 301-307. doi:10.1007/s00280-007-0476-x

[33] Krishnan, S., Rana, V., Janjan, N.A., Abbruzzese, J.L., Gould, M.S., Das, P., Delclos, M.E., Palla, S., Guha, S., Varadhachary, G., Evans, D.B., Wolff, R.A. and Crane, C.H. (2006) Prognostic factors in patients with unresectable locally advanced pancreatic adenocarcinoma treated with chemoradiation. Cancer, 107, 2589-2596. doi: $10.1002 /$ cncr. 22328 